\title{
Pre-sowing Treatment Enhanced Germination and Vigour of True Shallot (Allium cepa var. aggregatum) Seeds
}

\author{
Agung, I G.A.M.S.; Diara, I.W. ${ }^{2}$ \\ Department of Agroecotechnology, Udayana University, Bali, Indonesia
}

\begin{abstract}
The objective of this research was to sudy the effects of pre-sowing treatments to enhance germination, growth and transplanting of true shallot seeds. The experiment was conducted in the glasshouse at Tangtu village, Badung regency from August until November 2017. Germination experiment was carried out in petridishes, while that for seedling vigour and growth experiment was done in plastic pots containing sand and top soil mixture. Both experiments were designed as complete randomized design with eight concentrations of $\mathrm{KNO}_{3}(1,1.5$ and $2 \mathrm{M})$ and $\mathrm{GA}_{3}(100,150$ and $200 \mathrm{ppm})$. Those treatments were replicated four times. Seeds were soaked for 24 hours in each concentration of solution prior to planting in petridishes as well as in pots. Results of the experiment showed that $\mathrm{GA}_{3}$ significantly increased germination percentage, speed of germination (57-63\% germinated seeds at 1 dap), index of seedling vigour, II. speed of seedling emergence $\left(34,39 \%\right.$ day $\left.{ }^{-1}\right)$ and percentage of seedlings having one true leaf (52\%) at 9 dap. The effects of $\mathrm{KNO}_{3}$ on those variables were not significantly different from those of $\mathrm{GA}_{3}$ except on speed of seedling emergence. $\mathrm{KNO}_{3} 2 \mathrm{M}$ and $\mathrm{GA}_{3}$ (100, 150 , 200 ppm) resulted in 12 days earlier in transplanting seedlings than control.
\end{abstract}

Keywords- Germination, pre-sowing, true shallot seeds, vigour.

\section{INTRODUCTION}

The True shallot seeds (TSS) are increasingly used by farmers in Indonesia. The benefits of TSS are free from pathogen, smaller number of planting materials, easier transporting and storaging, producing healthier crops and bigger bulbs (van den Brink and Basuki, 2011). The use of TSS is economically beneficial as well, due to doubling the yields compared to seed bulb crops. The problem in using TSS is that seeds have to be grown in the nursery for 20-25 days and after that have to be transplanted into the field, therefore needs longer time to produce bulbs compared to seed bulb (bulb-propagated) crops, therefore needs longer time to produce bulbs compared to seed bulb crops. To reduce the time in the nursery efforts have to be done to increase the germination of the seeds and faster estabishment of seedlings. The use of priming and pre-sowing methods have been succeeded to improve the speed of germination, increase germination percentage and reduced the amount of abnormal seedlings of onion (Allium cepa cv. aggregatum L.) (Caseiro et al., 2004, Tajbakhsh et al., 2004, Sevarani and Umarani, 2011, Jagosz, 2015). Seed priming treatments were also reported to be able to increase germination capacity of parsley (Petroselinum crispum L.) (Dursun and Ekinel, 2010), tomato (Lycopersicum esculentum L.) (Mirabi and Hasanabadi, 2012; Lara et al., 2014), carrot (Daucus carota L.) (Sevarani and Umarani, 2011) and is a suitable method of shortening the time for early crops (Barlow and Haigh, 1987).

The role of $\mathrm{KNO}_{3}$ in promoting germination of tomato seeds was also reported by Lara et al. (2014) and in increasing speed of seed germination and establishment of Ramonda serbica and Ramonda nathaliae by Gashi ( 2012). Gibberellin has roles in control and promote seed germination. $\mathrm{GA}_{3}$ enhances biochemical reaction of hydrolase (particularly $\alpha$ amylase) enzyme synthesis in endosperm of cereal grains. Gibberellic acid stimulates seed germination through $\alpha$ amylase synthesis (FinchSavage and Leubner, 2006). Effects of $\mathrm{GA}_{3}$ at concentration of $1000 \mathrm{ppm}$ combined with $0.3 \% \mathrm{KNO}_{3}$ were reported to result in the highest final germination percentage on Ramonda serbica, while the concentration of 500 ppm $\mathrm{GA}_{3}$ gave higher germination percentage on $R$. nathalie (Gashi et al., 2012).

Seed priming by soaking the seeds in $\mathrm{KNO}_{3}$ solution prior to planting is expected to increase germination and seedling establishment of true shallot seeds compared to those of seed bulb crops. If the seedlings are growing faster and stronger enough to be transplanted from the nursery into the field, the seedling growth could catch up with the growth of seed bulb crops. This research has an objective to study the effect pre-sowing treatments of $\mathrm{KNO}_{3}$ and $\mathrm{GA}_{3}$ concentrations on seed germination and seedling establishments of true seed shallots. 


\section{MATERIALS AND METHODS}

The experiment was conducted in the glasshouse in the village of Tangtu, Badung regency from 29 August 2017 until 21 September 2017. The commercial seeds of shallot cv. Tuk-Tuk (produced by PT. East West Indonesia, Cap Panah Merah) used in this experiment The $\mathrm{KNO}_{3}$ solutions were prepared at the concentrations of respectively $1,1.5$ and $2 \mathrm{M}$, while those of $\mathrm{GA}_{3}$ were respectively 100, 150 and $200 \mathrm{ppm}$. Distilled water was used as control. An amount of 50 seeds were subjected to priming by soaking them in $25 \mathrm{ml}$ of each solution concentration for 24 hours prior to planting. The treatments were arranged in a randomized complete design with four replicates making 28 units for each experiment.

Half amount of seeds were then cultured in petri dishes on a single sheet of Whatman No.1 filter paper, moistened with distilled water, kept on a glasshouse bench in $25 \pm 1^{\circ} \mathrm{C}$ room temperature. Another 25 seeds for each treatment were planted in a plastic pot of a pot of $12 \mathrm{~cm}$ diameter having $600 \mathrm{~g}$ of mixture of sand and fertile potting soils. Pots were watered to field capacity and leave for $24 \mathrm{~h}$ before planting and a volume of $50 \mathrm{ml}$ water was given to all pots every day.

Seed germination was monitored and counted everyday, and a seed was considered to be germinated when the radicle was $2 \mathrm{~cm}$ long (Soltani et al, 2015).

Data were recoded daily on germination percentage (GP) of normal seedlings (protrusion of radicles of $2 \mathrm{~cm}$ long in the petridishes for 7 days (Heydecker and Coolbear, 1977; Gashi et al., 2012; Jagosz, 2015), calculated using the following formulas:

$$
\mathrm{GP}(\%)=\frac{(\text { number of germinated seeds })}{\text { (number of total seeds) }} \times 100 \%
$$

where $D$ is the number of days counted from the beginning of germination, and $G$ is the number of seeds which germinated on day $D$ (Moradi et al., 2008; Jagosz, 2015).

The development of seed germination ( $\%$ germinated seeds day $^{-1}$ ) was also calculated in petridishes

Seedling vigour index (SVI), the speed of seedling emergence (SSE), and percentage of seedlings having true leaves (at least one true leaf has been developed) (PSTL) were recorded in pot experiment. Seedling vigour index (Hossain et al., 2006; Zanjan and Asli, 2012) was calculated as:

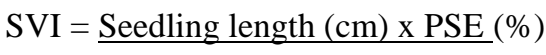

100

The criteria of PSE was similar to that of GP. Seedling length was randomly measured on five seedlings from the root to the hypocotyl and cotyledon at 9 DAP (De Souza et al., 2014). The speed of seedling emergence (SSE) was calculated using formula according to Islam et al. (2003):
SSE $=$ (number of seedlings emerged at 1 DAP) $\mathrm{X} 100$ (4)

(number of seedlings emerged at 9 DAP)

Percentage of seedlings having true leaves ((at least one true leaf has been developed) (PSTL).

The pot experiment was terminated 21 DAP at which seedlings were harvested and parameters were evaluated. Data collected from the experiments were analyzed statistically with ANOVA using CoStat and MstatC computer softwares and means were compared based on 5\% Least Significant Different test.

\section{RESULTS AND DISCUSSION}

$\mathrm{GA}_{3}$ solution significantly $(\mathrm{p}<0.05)$ affected individually all variables measured in this research as indicated by germination percentage (GP), development of seed germination (in petridish experiment), seedling vigour index (SVI), speed of seedling emergence (SSE) and percentage of seedlings having true leaves (PSTL) (pot experiment). The first true leaf on some seedlings was appeared 9 DAP.

\subsection{Germination Percentage (GP), and The Development of Seed Germination}

Soaking the seeds in $\mathrm{GA}_{3}$ and $\mathrm{KNO}_{3}$ concentrations, except $\mathrm{KNO}_{3} 2 \mathrm{M}$, resulted in significantly $(\mathrm{p}<0.05)$ higher germination percentage compared to the other treatments (Fig.1). The treatments of $\mathrm{GA}_{3}$ (100 ppm, 150 ppm and $200 \mathrm{ppm}$ ) and $\mathrm{KNO}_{3} 1 \mathrm{M}$ increased germination percentage of TSS $25.1 \%$ higher than control. $\mathrm{KNO}_{3}$ concentration of 1.5 and $2.0 \mathrm{M}$ did not significantly increased seed germination percentage. The use of KNO3 infact has important role in increasing germination of shallots as nitrate provided exogenously acts as a signal molecule favouring germination (Alboresi et al., 2005). The nitrate could be absorbed during soaking, being used in the metabolism of the embryo, through the activity of enzyme nitrate reductase (NR). This enzyme activity in the production of nitrite/nitric oxide couls act in promoting a faster germination (Lara et al., 2014).

Gibberellins, as growth hormones, have a role to enhance germination besides other functions such as stimulate cell elongation, flowering and fruiting. $\mathrm{GA}_{3}$ promotes a biochemical reaction i.e. the synthesis of hydrolase (particular $\alpha$ amylase) in endosperms of cereal seeds (Finch-Savage and Leubner, 2006). The positive effects might be due to its role in influencing the permeability of the membranes which ultimately leads to activation of enzymes involved in protein synthesis and carbohydrate metabolism (Preece and Read, 1993). The effect of $\mathrm{GA}_{3}$ $1000 \mathrm{ppm}$ combined with $0.3 \% \mathrm{KNO}_{3}$ was reported to result in the highest final germination percentage on Ramonda serbica, while the concentration of $\mathrm{GA}_{3} 500$ ppm gave higher germination percentage on $R$. nathalie 
(Gashi et al., 2012). The use of KNO3 infact has important role in increasing germination of shallots as nitrate provided exogenously acts as a signal molecule favouring germination (Alboresi et al., 2005). Increased germination percentage of onion seeds compared to control was also reported by Duman (2002) and Yıldırım et al (2002).

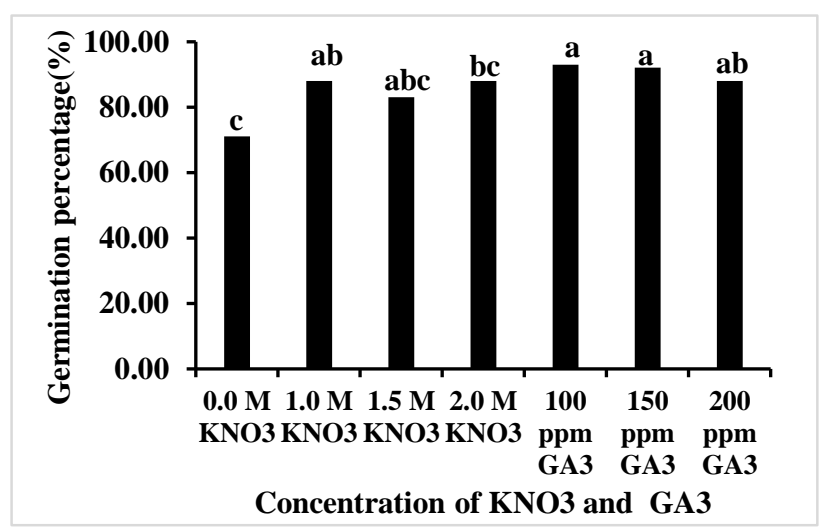

Fig. 1: Effect of $\mathrm{KNO}_{3}$ dan $\mathrm{GA}_{3}$ concentrations on germination percentage of true shallot seeds.

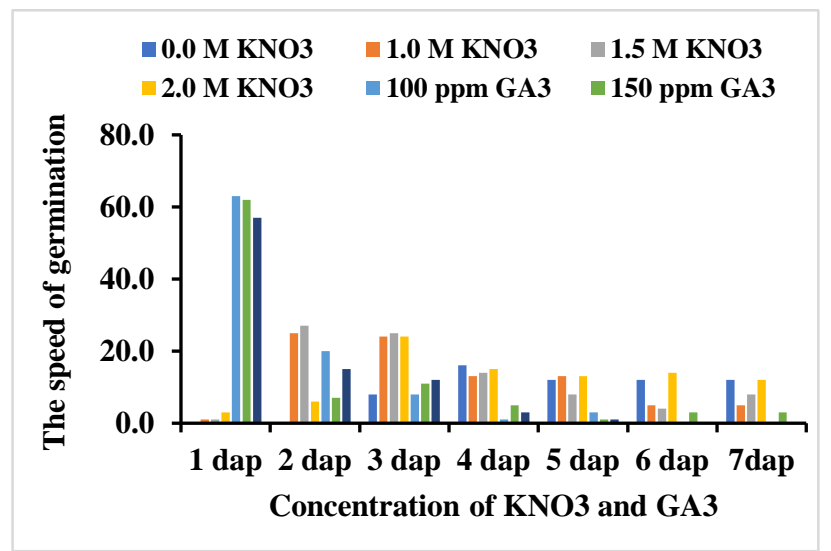

Fig.2: Effect of $\mathrm{KNO}_{3}$ dan $\mathrm{GA}_{3}$ concentrations on the speed of germination (\% germinated seeds day ${ }^{-1}$ ).

\subsection{Seedling Vigour Index (SVI)}

Vigour of seedling is an important factor to indicate the power of seedlings to grow and establish further. Such power is often reflected from seedling vigour index (SVI). The higher SVI indicates higher vigour of the seedling, guarantying they can be survived in unfavourable condition for growth. In this experiment $\mathrm{GA}_{3}$ and $\mathrm{KNO}_{3}$ concentrations resulted in average seedling vigour index of 2.43 higher than control (Fig. 3). The effects of $\mathrm{GA}_{3}$ concentration were not significantly different from that of $\mathrm{KNO}_{3}$ although this compound's ability in increasing seed germination was significantly lower. Higher average seedling vigour index indicated higher potential of seedlings to determine the potential for rapid uniform emergence and development of normal seedlings under a wide range of field conditions.
Increased seedling length due to effects of $\mathrm{KNO}_{3}$ concentration could be resulted in vigourous seedlings, the similar effect found in tomato (Farooq et al., 2005). The ability of $\mathrm{GA}_{3}$ in increasing seedling vigour was associated with the role of $\mathrm{GA}_{3}$ as an activator of seed germination (Finkelstein et al., 2008) and as a promoter of seedling elongation and growth.

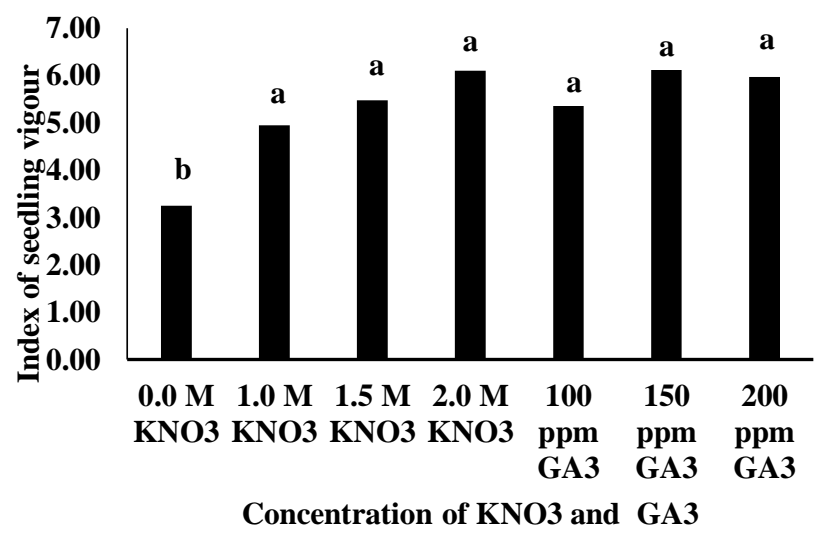

Fig. 3: Effect of $\mathrm{KNO}_{3}$ dan $\mathrm{GA}_{3}$ concentrations on index of seedling vigour

\subsection{The Speed of Seedling Emergence (SSE)}

The calculation of this variable involves number of seedlings emerge at one dap. multiply by 100 then divided by number of total seedlings emerged (Islam et al. (2003). $\mathrm{GA}_{3}$ resulted in average of seedlings emergence (SSE) significantly $34.39 \%$ higher than that of $\mathrm{KNO}_{3}$ as well as control (Fig. 4). This could be due to better permeability of the membranes, which contribute activation of enzymes involved in protein synthesis and carbohydrate metabolism (Preece and Read, 1993). Rapid emergence rate after priming or soaking may be due to increased rate of cell division in the root tips of primed seedlings as reported in wheat (Bose and Mishra, 1992) and in tomato (Farooq et al., 2005). Results of this experiment was not in line with that of Frett et al. (1991) on tomato, Demir and Mavi (2004) on watermelon and Govinden-Soulange and Levantard (2008) on other plant species, who reported that priming with $\mathrm{KNO}_{3}$ increased emergence of seedlings.

3.4 Percentage of seedlings having true leaves (PSTL) The effect of concentration of KNO3 $2 \mathrm{M}$, which was not significantly different from that of $\mathrm{GA}_{3}$ (100, 150 and 200 $\mathrm{ppm}$ ), resulted in $52 \%$ higher seedlings having at least one true leaf at the of 9 dap. The lower concentration of $\mathrm{KNO}_{3}(1$ and $1.5 \mathrm{M})$ produced significantly lower percentage of seedlings having at least one true leaf, although they were still higher than that in control (Fig. 5). Nitrate $\left(\mathrm{NO}_{3}\right)$ that was absorbed during soaking, then used in the metabolism of the embryo, and as a nitrogen source may contribute to seedling growth and early vegetative development. $\mathrm{KNO}_{3}$ as nitrogen-source 
fertilizer has a role in promoting vegetative growth of seedlings. $\mathrm{GA}_{3}$, due to its role in stimulating cell elongation, also contributes to seedling growth. The treatment of $\mathrm{GA}_{3}$ resulted in $34.39 \%$ more seedlings emerged in comparison to the average effect of KNO3 as well as control (Fig. 4). Seeds with high speed of emergence are indicated by their high emergence index (SVI).

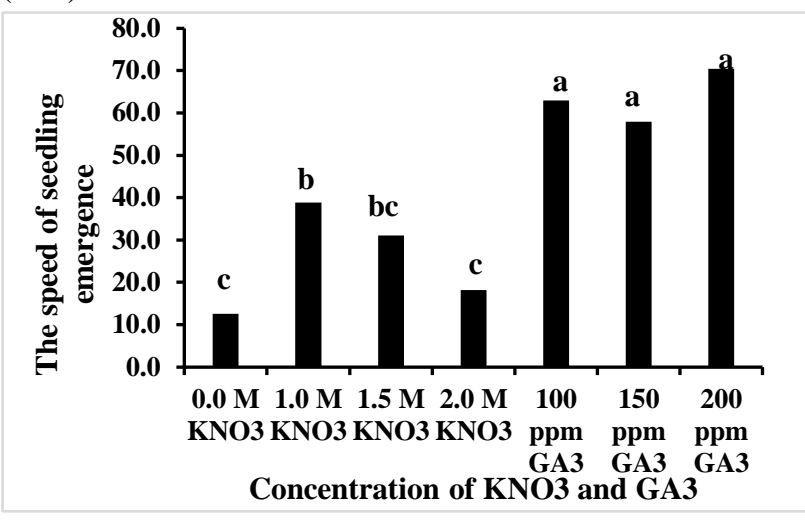

Fig. 4: Effect of $\mathrm{KNO}_{3}$ dan $\mathrm{GA}_{3}$ concentrations on the speed of seedling emergence (\% emerged seedlings day ${ }^{-1}$ )

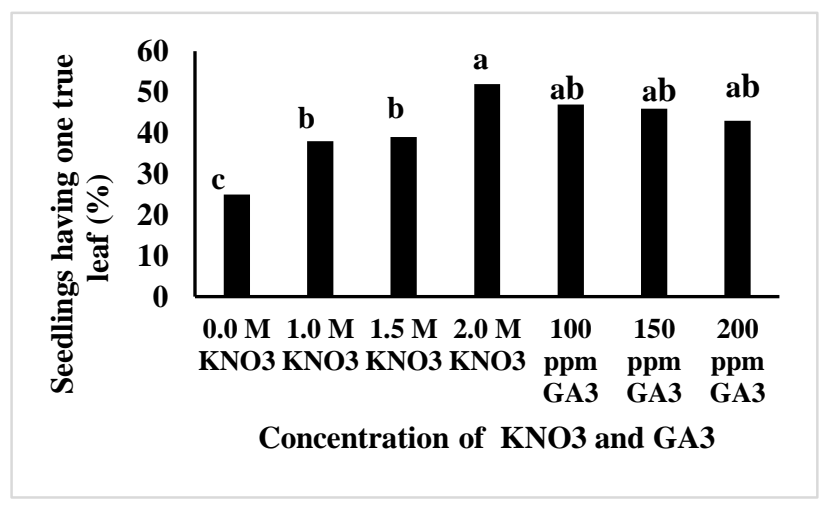

Fig. 5: Effect of $\mathrm{KNO}_{3}$ dan $\mathrm{GA}_{3}$ concentrations on the percentage of seedlings having one true leaf.

\section{CONCLUSION}

$\mathrm{GA}_{3}$ significantly enhanced: a) seed germination percentage $(25,1 \%$ higher than control), b) The speed of seed germination (57-63\% germinated at 1 dap, compared to other treatments), c) index of seedling vigour $(2,43$ compared to control), d) the speed of seedling emergence $\left(34,39 \%\right.$ seedlings day ${ }^{-1}$ higher than $\left.\mathrm{KNO}_{3}\right)$, e) percentage of seedlings having at least one first leaf (true leaf) $(52 \%$ at 9 dap). $\mathrm{KNO}_{3}$ also had similar significant effects on the same variables, except on the speed of seed germination, the speed of seedling emergence and percentage of seedlings having one true leaf. Pre-sowing treatment with $\mathrm{GA}_{3}$ dan $\mathrm{KNO}_{3} \quad 2 \mathrm{M}$ enhanced time of seedling transplanting to the field (12 days earlier than with no pre-sowing treatment).

\section{ACKNOWLEDGEMENTS}

The authors gratefully thank the Ministry of Research,Technology and Higher Education Republic of Indonesia through University of Udayana for granting research funds of PNBP Group Research program in 2017.

\section{REFERENCES}

[1] Afzal, I., Basra, S.M.A. and Iqbal, A. (2005). The effects of seed soaking with plant growth regulators on seedling vigour of wheat under salinity stress. Journal of Stress Physiology and Biochemistry 1 (1): 6-14.

[2] Alboresi, A., Gestin, C., Leydecker, M.T., Bedu, M., Meye, C., Truong, H.N. (2005). Nitrate, a signal relieving seed dormancy in arabidopsis. Plant Cell Environment 28 (4): 500-512.

[3] Amjad, M. K., Ziap, K., Iqbal, Q., Ahmad, I., Riaz, M.A. and Z.A. Saqib. Effect of seed priming on seed vigour and salt tolerance in Hot pepper. (2007). Pakistan Journal of Agricultural Sciences 44 (3): 408-416.

[4] Argerich, C.A. and Bradford, K.J. (1989). The effects of priming and ageing on seed vigor in tomato. Journal of Experimental Botany 40 (5): 599607.

[5] Barlow, E.W.R. and Haigh, A.M. (1987). Effect of seed priming on the emrgence, growth and yield of UC $82 \mathrm{~B}$ tomatoes in the field. ISHS Acta Horticulturae 200:II. International Symposium on Processing tomatoes, XXV IHC, Davis, 1 March 1987, 22(1).

[6] Bose, B. and Mishra, T. (1992). Response of wheat seed to presowing seed treatment with $\mathrm{Mg}\left(\mathrm{NO}_{3}\right)_{2}$. Annual Agriculture Research 5:11-16.

[7] Bray, C.M., Davidson, P.A., Ashraf, M. and Taylor,R.M. (1989). Biochemical changes during osmopriming of leek seeds. Annals of Botany 63:185-193.

[8] Caseiro, R., Bennett, M.A. and Marcos-Filho, J. (2004). Comparison of three priming techniques for onion seed lots differing in initial seed quality. Seed Science and Technology 32: 365-375.

[9] Cheib, A.L. and Garcia, Q.S. (2012). Longevity and germination ecology of seeds of endemic Cactaceae species from high-altitude sites in south-eastern Brazil. Seed Science Research 21:45-53.

[10] De Souza, A., Garcia, D. Sueiro, L. and Gilart. F. (2014). Improvement of seed germination, growth and yield of onion plants by extremely low frequency non- uniform magnetic fields. Scientia Horticulturae 176: 63-69. 
[11] Demir, I and Mavi, K. (2004). The effect of priming on seedling emergence of differentially matured watermelon (Citrullus lanatus (Thunb.) Matsum and Nakai) seeds. Scientia Horticulturae 102 (4): 46747.

[12] Duman, İ. (2002) Soğan (Allium cepa L.) tohumların inçimlenmesini iyileştirici farkl 1 osmotik uygulama yöntemlerinin karş 1laşt ırılmas 1. Ege Üniversitesi Ziraat Fakültesi Dergisi 39 (2): 1-8.

[13] Dursun, A. and Ekinsi, M. (2010). Effects of different priming treatments and priming durations on germination percentage of parsley (Petroselinum crispum L) seeds. Agricultural Sciences 1 :17-23.

[14] Farooq, M., Basra, S.M.A., Saleem, B.A., Nafees, M. and Chrishti, S.A. (2005). Enhancement of tomato seed germination and seedling vigour by osmopriming. Pakistan Journal of Agricultural Sciences 42 (3-4): 36-41.

[15] Farooq, M., Basra, S.M.A., Saleem, B.A., Nafees, M., Gashi, B., Abdullai, K., Mafa, V. and Kongjika, E. (2012). Effect of gibberellic acid and potassium nitrate on seed germination of the resurrection plants Ramonda serbica and Ramonda nathaliae. African Journal of Biotechnology 11(20): 4537-4542.

[16] Govinden-Soulange, J. and Levantard, M. (2008). Comparative studies of seed priming and pelleting on percentage and mean time to germination of seeds of tomato (Lycopersicon esculentum Mill.). African Journal of Agricultural Research 3 (10): 725-731.

[17] Preece, J.E. and Read, P.E. (1993). Mineral Nutrition In: The Biology of Horticulture Crop 2nd ed., Jhon Wiley and Sons Publisher. P.257-259.

[18] Heydecker, W. and Coolbear, P. (1977). Seed treatments for improved-performan.ce-survey and attempted prognosis. Seed Science and Technology. 5: 353-425.

[19] Hossain, M. A., Arefin, M.K., Khan, B.M. and Rahman, M. A. (2006). Effects of seed treatments on germination and seedling growth attributes of Horitaki (Terminalia chebula Retz.) in the nursery. Research Journal of Agriculture and Biological Sciences 1(2): 135-141.

[20] Islam, A.K., Anuar, N. and Yaakob, Z. Effect of genotypes and pre-sowing treatments on seed germination behavior of jatropha. (2003). Asian Journal of Plant Science 8 (6), 433-439.

[21] Jagosz, B. (2015). Improving onion seed germination using priming treatments. Infrastructure and Ecology of Rural Areas IV (4): 147-1447.

[22] Khayeh-Hossaeni, M., Lomholt, A. and Mattews, S. (2009). Mean germination time in the laboratory estimates the relative vigour and field performance of commercial seed lots of maize (Zea mays L.). Seed Science and Technology 37 (1): 446-456.

[23] Maguire, J. D. (1962). Speed of germination - aid in selection and evaluation for seedling emergence and vigour. Crop Science 2: 176-177.

[24] Mattews, S. and Khayeh-Hossaeni, M. (2007). Length of the lag period of germination and metabolic repair explain vigour differences in seed lots of maize (Zea mays). Seed Science and Technology 35 (1): 200-212.

[25] Mauromicale, G. and Cavallaro, V. (1995). Effects of seed osmopriming on germination of tomato at different water potential. Seed Science and Technology 23: 393-40.

[26] Mirabi, E. and Hasanabadi, M. (2012). Effect of seed priming on some characteristic of seedling and seed vigour of tomato (Lycopercicum esculentum). Journal of Advance Laboratory Research in Biology III (III): 37-240.

[27] Mock, J. J. and Skrdla, W.H. (1978). Evaluation of maize plant introductions for cold tolerance. Euphytica 27: 27-32.

[28] Moradi, D.P., Sharif-zadeh, F., Janmohammadi, M. (2008). Influence of priming techniques on seed germination behaviour of maize inbred lines (Zea mays L.). Journal of Agriculture and Biological Sciences 3(3): 22-25.

[29] Oliveira, P.G. and Garcia, Q.S. (2001). Germination characteristics of Syngonanthus seeds (Eriocaulaceae) in campos rupestres vegetation in south-eastern Brazil. Seed Science Research 21(01): $39-45$

[30] Don, R. (2003). ISTA Handbook on seedling evaluation. 3rd ed. International Seed Testing Association, Zürich, Switzerland.

[31] Ramzan, A., Hafiz, L.A., Ahmad, T. And Abbasi, N.A. (2010). Effect of priming with potassium nitrate and dehusking on seed germination of gladiolus (Gladiolus alatus). Pakistan Journal of Botany 42 (1): 247-258.

[32] Selvarani, K. and Umarani, R. (201). Evaluation of seed priming methods to improve seed vigour of onion (Allium cepa cvaggregatum) and carrot (Daucus carota). Journal of Agricultural Technology 7(3): 857-867.

[33] Soltani, E., Ghaderi-Far, F., Baskin, C.C. and Baskin, J.M. (2015). Problems with using mean germina tion time to calculate rate of seed germination. Australian Journal of Botany 63: 631635.

[34] Tajbakhsh, M., Brown, P.H., Gracie, A.J., Spurr, C.J., Donovan, N. and Clark, R.J. (2004). 
Mitigation of stunted root abnormality in onion (Allium cepa L.) using seed priming treatments. Seed Science and Technology 32: 683-692.

[35] van den Brink, L. and Basuki, R.S. (2011). Production of true seed shallots in Indonesia. ISHS Acta Horticulturae 958: I International Symposium on Sustainable Vegetable Production in Southeast Asia.

DOI:10.1.7660/Acta.Hortic.2012.958.12.Sustainable Vegetable Production in Southeast Asia. DOI: 10.1.7660/Acta.Hortic.2012.958.12.

[36] Yıldırım, E., Dursun, A., Güvenç, İ. and Kumlay, A.M. (2002). Effects of different seed germination of some vegetable species. Acta Agrobotanica 55 (2), 75-80.

[37] Zanjan, M.G. and Asli, D.E. (2012). A study of seed germination and early seeding growth of wheat genotypes affected by different seed pyridoxinepriming duration. Annals of Biological Research 3 (12): 5687-5691. 